University of Nebraska - Lincoln

DigitalCommons@University of Nebraska - Lincoln

Textile Society of America Symposium

Proceedings

Textile Society of America

2020

Viscacha: luxury, fate and identification in Precolumbian Textiles

Elena Phipps

Textile Society of America, elena@ephipps.org

Caroline Solazzo

Smithsonian Institution, solazzoc@si.edu

Follow this and additional works at: https://digitalcommons.unl.edu/tsaconf

Part of the Art and Materials Conservation Commons, Art Practice Commons, Fashion Design Commons, Fiber, Textile, and Weaving Arts Commons, Fine Arts Commons, and the Museum Studies Commons

Phipps, Elena and Solazzo, Caroline, "Viscacha: luxury, fate and identification in Precolumbian Textiles" (2020). Textile Society of America Symposium Proceedings. 1183.

https://digitalcommons.unl.edu/tsaconf/1183

This Article is brought to you for free and open access by the Textile Society of America at DigitalCommons@University of Nebraska - Lincoln. It has been accepted for inclusion in Textile Society of America Symposium Proceedings by an authorized administrator of DigitalCommons@University of Nebraska - Lincoln. 


\title{
Viscacha: luxury, fate and identification in Precolumbian Textiles
}

\author{
Elena Phipps and Caroline Solazzo
}

\section{Introduction}

Our understanding of the choices weavers make in the use of specialized materials comes from the investigation of both the cultural significance of their source, and their physical identification. In this paper, we will present the historical context for the use of special fibers from the viscacha--a rodent related to chinchilla--and examine the cultural significance of the animal in Andean history, while developing scientific methods through proteomic analysis to enable their identification in a selected group of museum textiles. ${ }^{1}$ This kind of collaborative work draws on the interface between art history and archaeology, ethnohistory, conservation and science and underscores the importance of material-based studies within the complex matrix of art, culture and society.

\section{Part 1: Cultural Context}

The viscacha is a small animal related to the chinchilla, that has a long tail, tall ears, whiskers and extremely soft body hair and lives in the highland regions of the Andes. (Fig. 1) It is one of the exotic animal hairs, along with jaguar, puma and wild guanaco, thought to have been used in Peru for special items, though rarely included in discussions of Andean fibers which generally are centered around the predominance of camelids and cottons.

The chinchillidae family is a small family of only three genera: the Chinchilla genus, the Lagidium genus and the Lagostomus genus. ${ }^{2}$ Chinchilla and Lagidium are native to the Andes mountains that include parts of Bolivia, Peru, Argentina and Chile. ${ }^{3}$ The two main species of mountain viscacha are the northern viscacha (Lagidium peruanum) and the southern viscacha (Lagidium viscacia) with a few more species and sub-species. The plains viscacha (Lagostomus maximus), the only living species within the genus Lagostomus, is found in Argentina, Bolivia, and Paraguay. The ranges of mountain and plains viscacha do not overlap. ${ }^{3}$

\footnotetext{
${ }^{1}$ The research project has taken place over a number of years, and through a number of phases-- we are most grateful to our colleagues who have contributed to the study with their own additions and sightings of potential samples for investigation. The authors wish to thank our colleagues who contributed to the project including: Rautenstrauch-Joest-Museum, Cologne - Petra Czerwinske-Eger, Conservator; Museum of Fine Arts BostonMeredith Montague, Conservator; George Washington University/Textile Museum - Maria Fusco, Conservator; American Museum of Natural History, NY - Kristen Mable, Vuka Roussakis and Sumru Aricanli, Division of Anthropology and Neil Duncan, Division of mammals; National Museum of Natural History - Ingrid Rochon and Darrin Lunde, Division of Mammals; Cooper Hewitt National Design Museum Smithsonian - Matilda McQuaid and Kira Eng-Wilmot; Museum Conservation Institute - Thomas Lam (SEM images), among others.

${ }^{2}$ Angel E. Spotorno, John P. Valladares, Juan C. Marin, R. Eduardo Palma, Carlos Zuleta R., Molecular Divergence and Phylogenetic Relationships of Chinchillids (Rodentia: Chinchillidae), Journal of Mammalogy, Volume 85, Issue 3, June 2004, Pages 384-388, https://doi.org/10.1644/BRB-119.

${ }^{3}$ Pearson, Oliver P. "Life History of Mountain Viscachas in Peru." Journal of Mammalogy, vol. 29, no. 4, 1948, pp. 345374. JSTOR, www.jstor.org/stable/1375125. Accessed 19 Jan. 2021.
} 


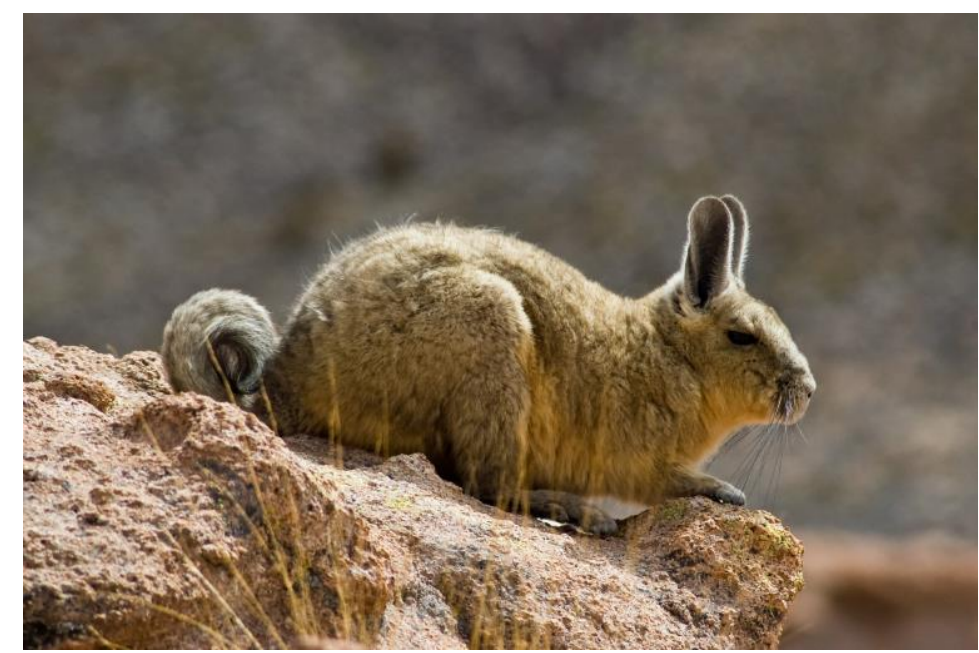

Fig. 1 Langidium viscacha. Bolivia. (Photo: Alexandre Bruisse)

Curiously, depictions of viscacha are found in a number of Andean tapestries produced in the Colonial period, notably from the $16^{\text {th }}-18^{\text {th }}$ centuries. The tapestries, with their hybrid designs that incorporated both Andean and Spanish elements, combined with the technical features that continued, to some extent, the weaving methods from the Inca period represent the complex interchange between the indigenous cultures of the Andes and the Spanish colonial world. The repeated inclusion of the image of the viscacha in this context spurred this present investigation into their meaning. This feature especially came into focus on the occasion of the exhibition The Colonial Andes: Tapestries and Silverwork 1530-1830 at the Metropolitan Museum of Art in 2004, when a number of these tapestries were brought together for the first time, from collections in South America, Europe and the USA, which enabled closeup study of their complex and detailed iconography. ${ }^{4}$ In one beautiful late sixteenth century tapestry, belonging to the Museum of Fine Arts, Boston, for example, with its European format of concentric boarders and broad central field with the Spanish-style interlace design, centered at the top and bottom of the tapestry were two small, quirky, light gray/blue animals, almost imperceptible, and not seen in any other part of the tapestry. ${ }^{5}$ Looking further in other tapestries, one could see that off in a corner or subtlety masked by a plethora of other lively visual motifs, were a series of small, longtailed animals depicted, most often, in a blue color. We see one nibbling Adam's calf, in the $16^{\text {th }}$ c. tapestry of the Birth of Eve (from Adam's rib). ${ }^{6}$ (Fig. 2a and b) Additionally, they show up among the acanthus leaves in the border of a fine early tapestry with neo Inca designs, as well as scattered among the roses in a mantle for Santa Rosa de Lima, (Fig. 3) and in the corners and central roundel of the $17^{\text {th }}$ c. "Lotto- style" tapestry carpet.

\footnotetext{
${ }^{4}$ Elena Phipps, Johanna Hecht and Christina Esteras The Colonial Andes: Tapestries and Silverwork 1530-1830. New York: Metropolitan Museum of Art, 2004.

${ }^{5}$ See Phipps Colonial Andes Cat no. 52 and 53, 212-6.

${ }^{6}$ See I. Iriarte in Colonial Andes Cat no 92, 282-294.

${ }^{7}$ Tapestry with acanthus leaves, MFA Boston accession number 04.123. Tapestry with Lotto-style design, MFA Boston 1970.502- see Phipps Colonial Andes Cat no. 70, 238-240.
} 

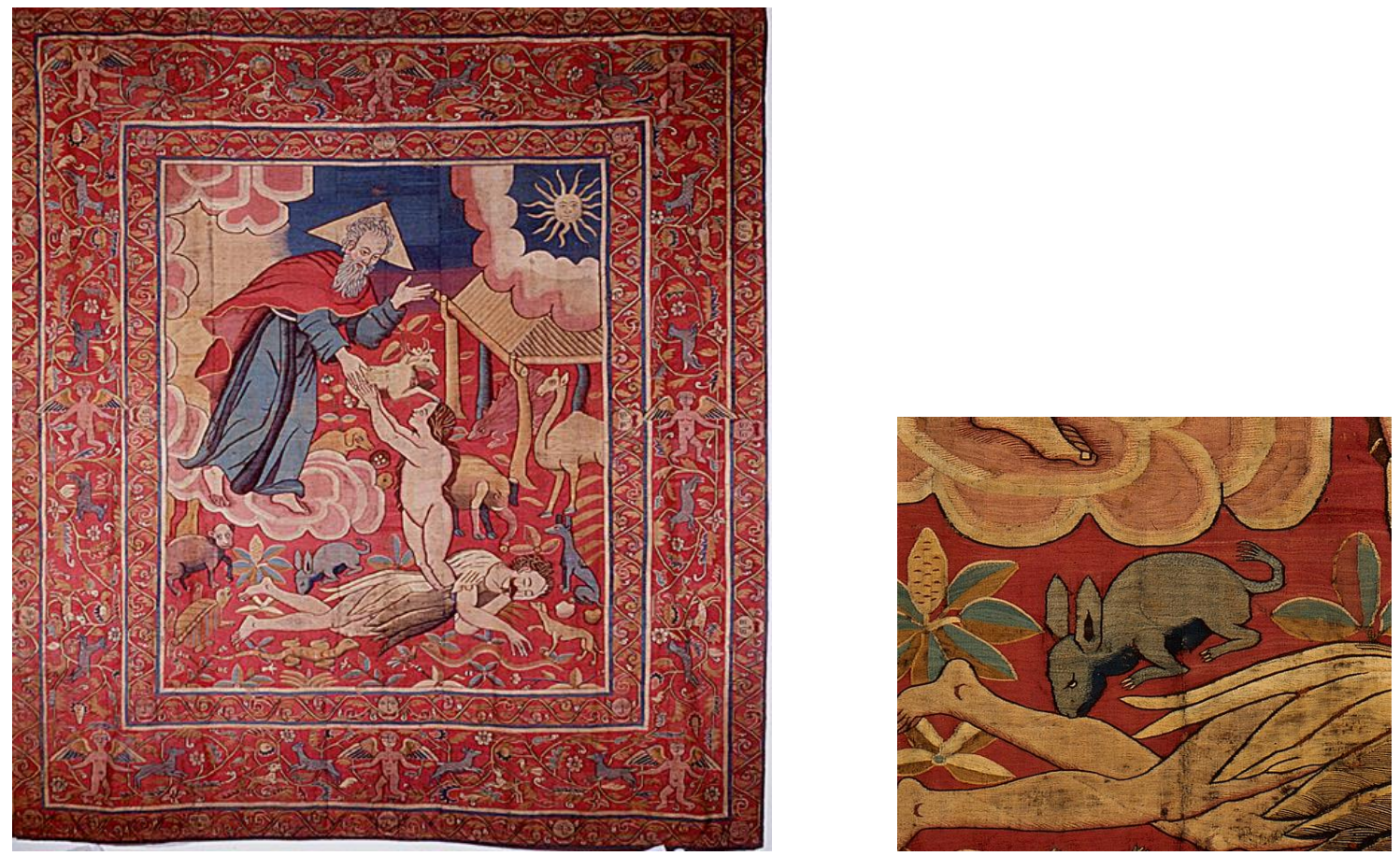

Fig. 2a and b Creation of Eve. Colonial Andean tapestry, early 17th c. Buenos Aires, Círculo de Armas. (Photo: after Colonial Andes, 2004.)

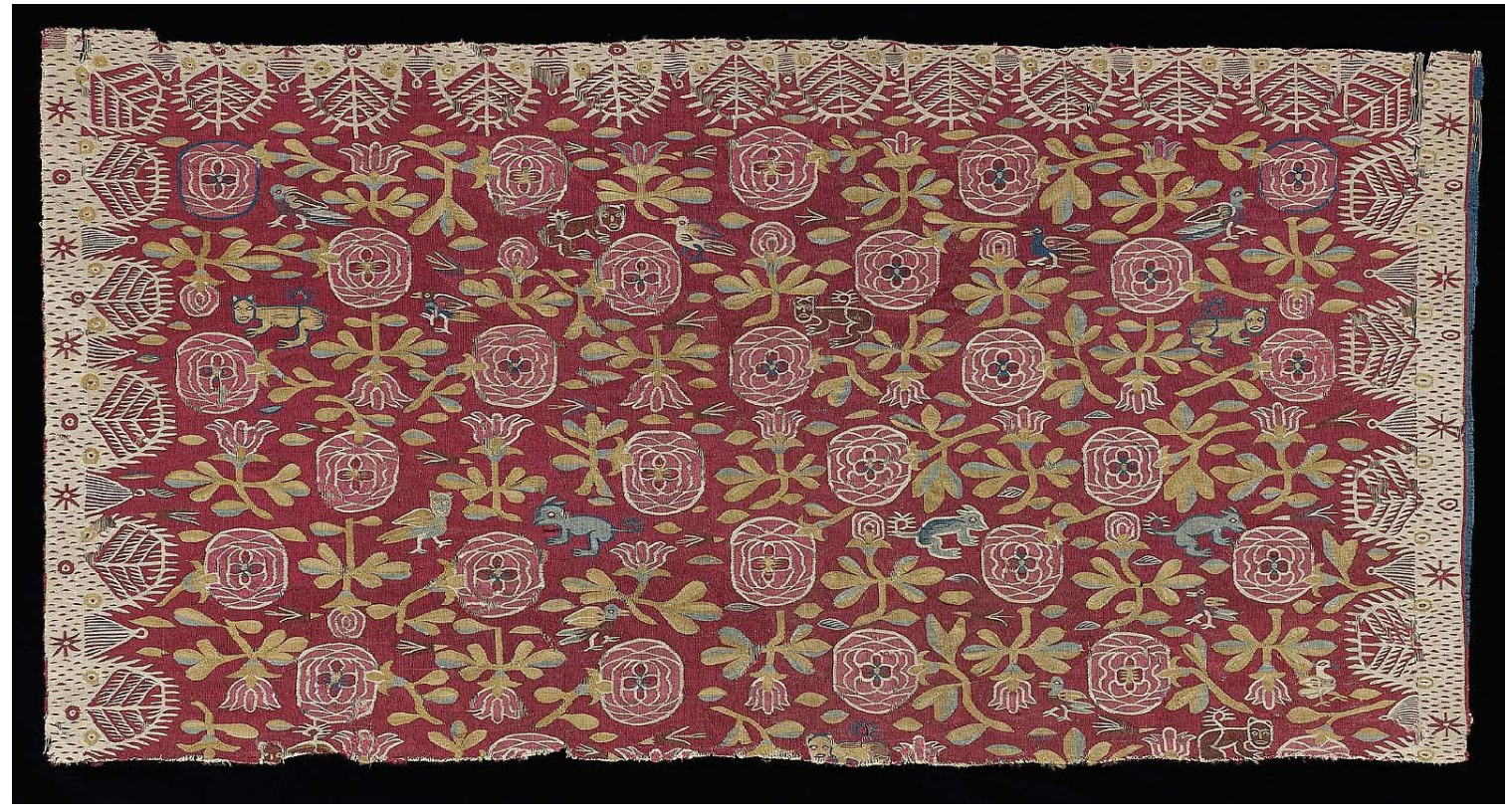

Fig. 3 Colonial Peruvian Tapestry (with roses), 16th-17th c. Museum of Fine Arts, Boston 07.844 Denman Waldo Ross Collection. (Photo courtesy MFA Boston: https://collections.mfa.org/objects/68763/fragment) 
Perhaps the most poignant example can be seen in the border of the fine wreath tapestry belonging to the museum in Munich (Fig. 4) seen here, with a pregnant coya (an Inca noble woman) with her offering basket of fruits, and cantuta flowers and her talismanic blue viscacha, who is upside-down. ${ }^{8}$

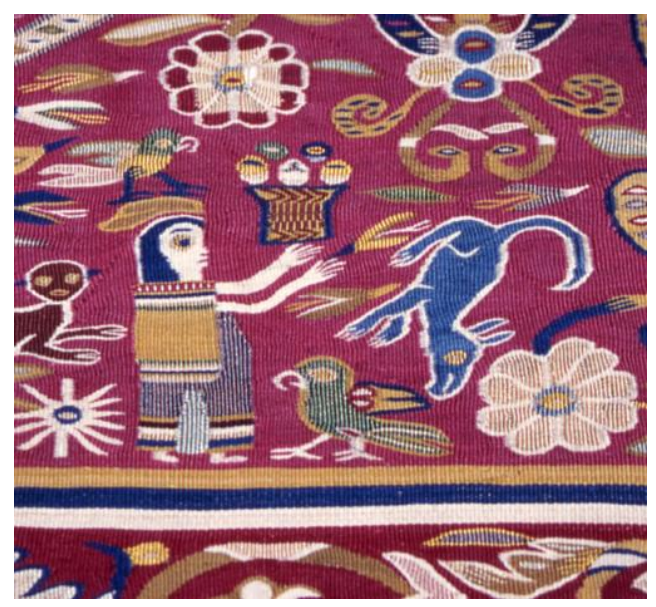

Fig. 4 Detail: Colonial Peruvian Tapestry with Wreath. Museum Fünf Kontinente (formerly Staatliches M. Fur Volkerkunde, Munich) 55-14-1. (Photo: after Colonial Andes, 2004).

What are these animals, why do they show up like this in Spanish style Andean tapestries, made in different workshops, in different time periods and different locales, and why are they depicted most often, in blue? We can identify the animal as viscacha however, understanding the intentionality and significance of their blue presence is a bit more complicated. We may understand this perhaps within the context of Andean ritual and mythological significance of the animal itself, and will explore this in the following discussion. The aspect of the repeated occurrence in a blue color requires more investigation into the cultural significance of the color, especially in Inca tradition. ${ }^{9}$

The term for viscacha in Quechua, and also in Aymara (the two primary languages of the Inca empire) is Uiskacha (or Huiskacha) and the representation of the animal is depicted in some Precolumbian textiles. (Fig. 5) The term is mentioned in early Colonial documents, such as Cieza de Leon, 1553 in his chronicle of Peru who notes that the 'wool' of the animal was very soft, as silk. ${ }^{10}$ Bernabe Cobo, in his 1653 , History of the Inca describes the color of viscacha as "monkish and ashen." Garcilaso de la Vega in his 1609 Royal Commentaries notes that "In the time of the Inca kings, and many years after, if someone has the opportunity to get some

\footnotetext{
${ }^{8}$ Phipps Colonial Andes Cat no 71, 240-2.

${ }^{9} \mathrm{We}$ can see that the Inca rarely used blue for garments produced under royal auspices, with a few notable exceptions that may signal other more esoteric meanings. See Phipps "Textile Colors and Colorants in the Andes" in Gerhard Wolf, Joseph Connors and Louis A. Waldman, eds. Colors between Two Worlds. Villa I Tatti, Florence. Harvard University Press, Cambridge. 2012, 256-280.

${ }^{10}$ Cieza de Leon Travels of Peru trans. C. Markham. London: Hakluyt Society, 1864, Chpt CXIV, 402.

11 "Frailesco y ceniciento." Cobo. He also comments that it is incorporated into the yarns used for royal Inca garments to give variability to the yarn. Obras de P. Bernabé Cobo, Francisco Mateos ed. Madrid: Atlas, 1964, 3601.
} 
Viscacha hair, they spin it to give variation to the colors of the fine cloth they weave. The color that it has is pardo claro [light brown], color of ash and it is very soft and smooth. It is a thing very highly regarded by the indios: they only use it in the clothing of the nobles." 12 And in the $18^{\text {th }} \mathrm{c}$ "Vizcacha" is illustrated in Jaime Balthazar Martinez Campañon (c. 1782-1785), vol V no. VI as one of the animals that inhabit the region of Trujillo.
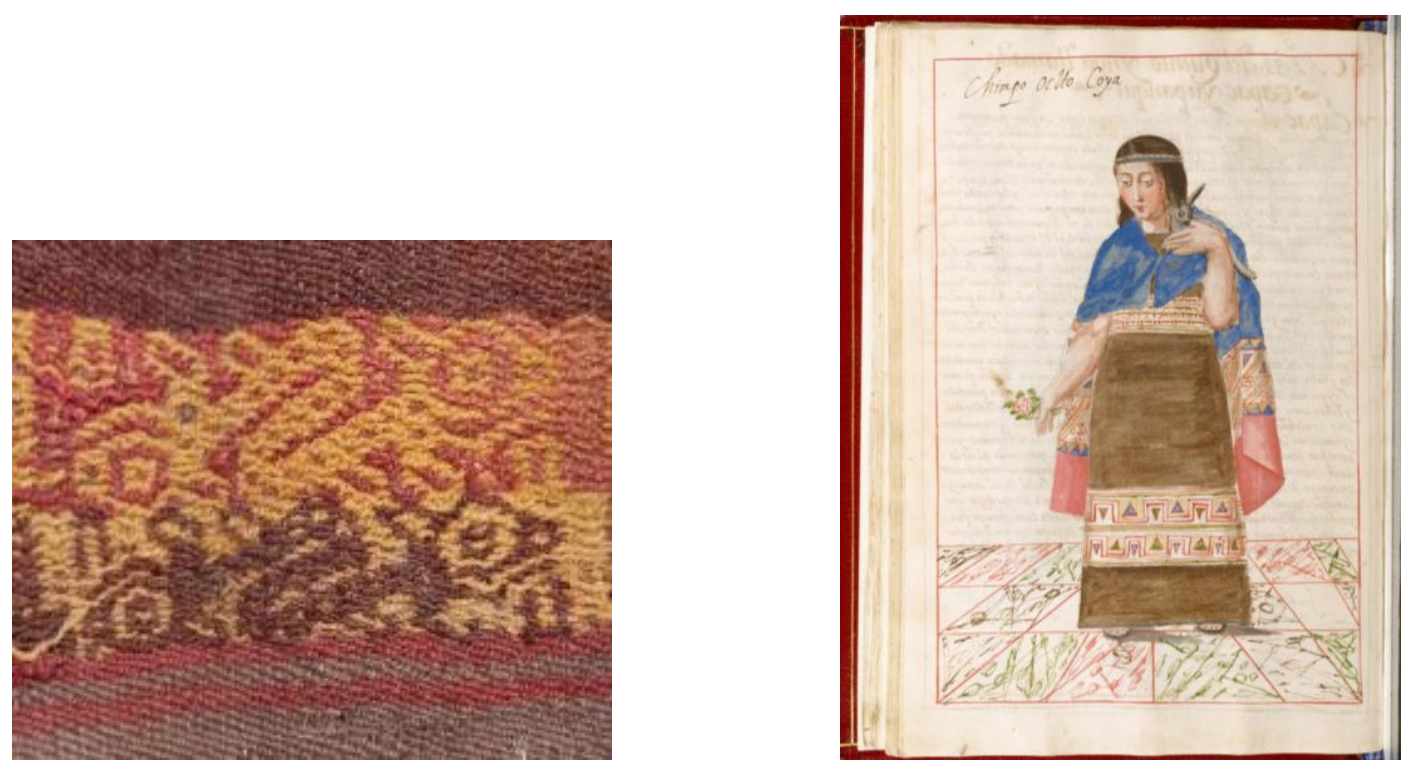

Fig. 5 Viscacha designs woven in a Precolumbian archaeological textile excavated in Huaca Malena, Valley of Asia. (Photo: Rommul Angeles)

Fig. 6 Chimpo Occlo Coya Martin de Murúa's 1616 Historia General del Pirú. Getty Museum Ms. Ludwig XIII 16 (83.MP.159) fol. $31 v$.

Martin de Murúa, in his Historia del Peru depicts Chimpo Coya, the wife of the second Inca, holding a small viscacha in her arms, confirming this association with the nobility. ${ }^{13}$ (Fig. 6) In spite of these numerous references, very few preserved textiles with viscacha hair have been identified. ${ }^{14}$

The animals live in some of the extreme environments, where water is scarce, such as in the highland salt-lake region of Bolivia. Cieza in his Chronicles, mentions that they are "born in the

\footnotetext{
${ }^{12}$ Garcilaso de la Vega. Historia General del Perú ó Commentarios Reales de los Incas, el Inca Garcilaso de la Vega. Nueva Edicion. Madrid: Imprenta del Villalpando, 1800, tomo V, 68-9 [Biblioteca Virtual Andalucía]

${ }^{13}$ Chimpo Coya, noted by Murúa for her golden bracelets and beautiful garments, she is also described as having 'thick thighs and calves" Martin de Murúa, Historia General del Piru Getty Museum Ms. Ludwig XIII 16 (83.MP.159) Chapter VI, 1616. In addition, I thank Gregory T. Cushman for identifying the animal in the coya's arms as a viscacha. (Cushman, Gregory T. "The Environmental Contexts of Guaman Poma: Interethnic Conflict over Forest Resources and Place in Huamanga (Peru), 1540-1600." In Unlocking the Doors to the Worlds of Guaman Poma and his Nueva Corónica, Edited by Rolena Adorno and Ivan Boserup, p. 87-140. Copenhagen: Museum Tusculanum Press, 2015).

${ }^{14}$ Spun viscacha hair (or its cousin, chinchilla) was found in Caserones, Chile around 950 B.C Amy Oakland. In Penelope Ballard Drooker and Laurie Webster, editors. Beyond Cloth and Cordage: Archaeological Textile Research in the Americas. Salt Lake City: Univ of Utah Press, 2002. 230-251. (p. 238 viscacha/chinchilla).
} 
rocky land, and inside caves." 15 And we see this today. Their characteristic fortitude for survival in this harsh terrain may contribute to the folkloric and almost mythic significance of the animal. Cobo, in 1653 also attributes medicinal and curing powers to the viscacha and notes that its hair is used in ceremony to cure deafness as well as fever from kidney's. ${ }^{16}$ To that end, a ritual offering bag made of viscacha skin (containing human hair inside) was found in an huntergatherer cave in northern Patagonia dated to around 1300 B.C. ${ }^{17}$ And other special bags made notably of viscacha and jaguar skins, along with ritual paraphernalia including hallucinogenic snuff tablets were found in a Tiwanaku-era archaeological context in Bolivia. (ca. 500-1100 A.D.) ${ }^{18}$

Remarks from a very knowledgeable local archaeologist and botanist Eduardo Pareja (who sadly recently passed away) while walking though the archaeological site of Tiwanaku, in the highland region of late Titicaca, tentatively identified some soft, fuzzy hair caught in the dry scrub brush as likely to have come from a viscacha. ${ }^{19}$ Further, he mentioned that local people-often women - make a yarn from the hair, which is spun to the left, and worn as an amulet around the wrist, to protect health, well-being, love and childbirth. Interestingly, Amy Oakland, in her important 1980s article about the meaning of left-spun yarn, mentions an archaeological find in Mojocoya, Bolivia of a burial of a young girl who was wearing a left-spun twisted cord around her wrist. ${ }^{20}$ The use of the special viscacha hair as an amulet worn around the wrist may imbue the item with even further significance. Left-spun yarn, called $l l o q$ 'e, has a history and significance, especially from the highlands. ${ }^{21}$ And this may be the case of the incredible Inca coca bag, which was part of our study - that is not only made almost entirely of viscacha hair yarns, but some of the yarns forming stripes, are the so-called left-spun lloq'e yarns (see below). Lloq'e is used in certain garments that may enhance their significance, but also, as described by Guaman Poma in his chapter on sorcery where even a single lloq'e yarn has agency and power, enough to defeat an enemy. ${ }^{22}$ Other items where yarns themselves carry importance in the Andes are the sets of knotted cords called khipu - which are generally composed of cotton or camelid hair yarns--have been used for record keeping since Precolumbian times. Recently, of great interest is one preserved in the Quechua community of San Juan de Collata, Peru reported by Sabine Hyland to have some cords of viscacha hair. ${ }^{23}$ With the presence of viscacha hair in these

\footnotetext{
15 "they are born in the rocky land, and inside rocas (caves)... the wool of these viscachas the indios make large mantas, very soft, as if made of silk and are precious." Cieza de León, Pedro de, Crónica Del Perú El Señorío De Los Incas, Franklin Pease G.Y, ed. Biblioteca Ayacucho, 2005, ch. 113:279.

${ }^{16}$ Cobo. Historia del Nuevo Mundo 1964, 361.

${ }^{17}$ Luciano Prates, Fernando Ballejo, Adriana Blasi Analysis of hair remains from a hunter-gatherer grave from Patagonia: Taxonomic identification and archaeological implications. Journal of Archaeological Science: Reports. Volume 8, August 2016, 142-146. https://doi.org/10.1016/j.jasrep.2016.05.064

${ }^{18}$ Skins for bags: Capriles F., José M Intercambio y uso ritual de fauna por Tiwanaku_Análisis de pelos y fibras de los conjuntos arqueológicos de Amaguaya, Bolivia. Estudios Atacameños 23- 2002, 33-51.

${ }^{19}$ personal communication Eduardo Pareja to Elena Phipps, May 2006.

${ }^{20}$ Amy Oakland, Pre-Columbian Spinning and Lloq'e Yarn: an ethnographic analogy. Andean Perspective Newsletter, Fall 1982, 25-29. Reference to Mojocoya burial on p. 27.

${ }^{21}$ See E. Phipps Woven Brilliance in Andean Textile Traditions for Textile Museum Journal 2020, Vol 47, $29-54$.

22 "Chapter on Common Witches" COMVN HICHEZEROS Guaman Poma de Ayala, in his 1616/1617 manuscript El primer nueva corónica y buen gobierno. Fol. 275 [277] GKS 2232 4º. Det Kongelige Bibliotek http://www5.kb.dk/permalink/2006/poma/277/en/text/?open=idm46287306214720.

${ }^{23}$ This khipu was composed of various cords made from native animals, whose fiber was identified by the community as vicuña, deer, alpaca, llama, guanaco, and viscacha. Sabine Hyland, Unraveling an Ancient Code
} 
archeologically, historically and ethnographically significant contexts - from ritual paraphernalia to record-keeping devices, the current research project was developed to try to find examples in Andean woven textiles.

\section{Part 2: Project for Identification and Analysis of Museum Samples}

The identification of viscacha hair with microscopy can be difficult - morphology from tip to root varies considerably, and varies amongst guard hairs and underfur, as well as scale pattern and medulla formations. This was learned from an earlier study of the first suspected example from a textile that came to attention during the Colonial project in 2004 - that after considerable study was found to be rabbit hair. ${ }^{24}$ Since so little has been documented about the use of viscacha hair in Precolumbian textiles, for the research project, criteria were developed to assess its potential presence. Relying on subjective characteristics that helped to identify the material character of this unusual fiber was important, but difficult: these fibers may be potentially recognizable through physical qualities - primarily the softness of their extremely fine touch, which may be similar to some of the finer alpaca and vicuña hairs and recognition of the coloring as a kind of mottled color that is not generally associated with the camelid hair. In addition, as this fiber was generally considered rare, there was an expectation that when used in a woven fabric, its use might be limited to certain features, rather than full cloth. Spun yarns may, according to the Colonial references, be found mixed with camelid, which further creates the need for judicious approach to microscopy and sample taking, but the fiber can also be used alone in a single yarn. So, as viscacha fiber may be confused with rabbit both visually and even under magnification, the expertise in protein analysis seemed to have potential for the accurate identification. But in this developing field of scientific analysis, preliminary establishment of known samples was required.

\section{Basics of proteomics analysis}

Over the past decade, proteomics has been extensively used to determine the species of animal fibers used in textiles. ${ }^{25}$ The hair proteome (i.e. the complete set of proteins composing the biological tissue) is composed of multiple families of alpha-keratins (structural proteins that take the form of alpha-helices) and keratin associated proteins (amorphous proteins). Two chains of alpha-keratins form a dimer and further bundle together to form the intermediate filaments that in turn are packed into cortical cells, thus conferring to the fiber a certain resistance to physical and chemical damage. The large and varied families of keratin associated proteins form the matrix that surrounds the intermediate filaments and are bound to keratins through disulfide bridges. The proteins are made of long chains of amino acids of which they are 20 different ones (represented by a letter, e.g. A for alanine, G for glycine) linked by peptidic bonds. While the hair proteome will be mostly similar between fur animals (usually same number and types of

\footnotetext{
Written in String. Sapiens Anthropology Magazine Nov 7, 2017 https://www.sapiens.org/language/khipu-andeanwriting/ Also: https://www.scientificamerican.com/article/unraveling-an-ancient-code-written-in-strings/ 11.09.2019

${ }^{24}$ The first suspected textile came to my attention during the Colonial project in 2004-results of the study were presented in TSA symposium 2006. See Phipps, Elena and Commoner, Lucy, "Investigation of a Colonial Latin American Textile" (2006). Textile Society of America Symposium Proceedings. 358. https://digitalcommons.unl.edu/tsaconf/358.

${ }^{25}$ Solazzo, C. 2019. "Characterizing Historical Textiles and Clothing with Proteomics." Conservar Património 31: 97-114.
} 
proteins), slight differences in the amino acid sequences of the proteins allow the identification of diagnostic markers used to differentiate fibers, generally down to the genus level. ${ }^{26}$

Due to the complexity of the hair proteome, including their 3D structure, the presence of low abundance proteins and possible degradation, proteins have to be unfolded, solubilized and cut into peptides to be amenable to mass spectrometry analysis. The peptides obtained from enzymatic digestion (typically trypsin, an enzyme that cuts proteins at the arginine and lysine residues, Fig. 7) are eluted according to their hydrophobicity by reversed-phase chromatography before been electro-sprayed to the mass analyzer. The eluted peptides are analyzed by their mass in MS mode and fragmented into their amino acid sequence in MS/MS mode (see Fig. 7). This analysis yields thousands of MS/MS spectra that can be matched to existing sequences by searching the data against public databases of protein sequences.

\section{Identification in the Chinchillidae family}

Identification by searching public databases, however, can only rely on those species which have been sequenced. Typically, only domestic species or species that have a commercial value have been sequenced, which is the case of the chinchilla, the viscacha's closest relative. Since no keratin sequence is currently available for viscacha, but the hair proteome of the chinchilla is known, a match to chinchilla can potentially indicate a match for any member of the Chinchillidae family, including mountain or plains viscacha.

We began the current project in 2019 to test samples selected from archaeological textiles in various museum collections; the following is a brief introduction to the samples, along with the preliminary results (Table 1$){ }^{27}$

\footnotetext{
${ }^{26}$ Solazzo, C., M. Wadsley, J. M. Dyer, S. Clerens, M. J. Collins, and J. Plowman. 2013. “Characterization of Novel $\alpha$-Keratin Peptide Markers for Species Identification in Keratinous Tissues Using Mass Spectrometry." Rapid Communications in Mass Spectrometry 27 (23): 2685-2698.

${ }^{27}$ For the proteomics analysis, this project was generously supported by: Smithsonian's Museum Conservation Institute Federal and Trust Funds, The Andrew W. Mellon Foundation - Museum Conservation Institute's Directorship Endowment (Grant \# G-40700657), Gifts from the estates of Dr. Georgette Kamenetz, John R. Huggard, Marguerite L. Bender, and John A. and Helen L. Burham, Sprague Endowment
} 


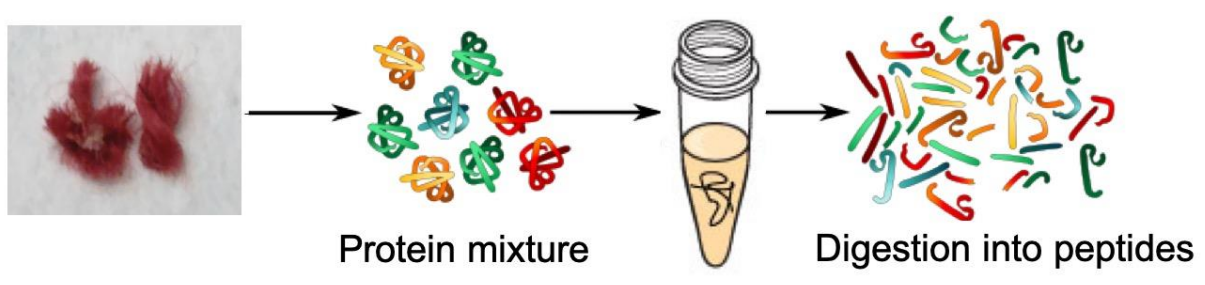

\begin{tabular}{ll} 
& MTGSCCGSFSSYSCGGGCLQPCCCR \\
MTGSCCGSFSSYSCGGGCLQPCCC & DPCCCR \\
RDPCCCRPVSCQTTVCRPVSCVPP & PVSCQTTVCR \\
ICEPCRPICCDPCGLQQGCCKPISCC & PVSCVPK \\
PSSCTAVVCRPCCWTSTGCQLLSVQ & PICEPCR \\
APCCRPPCCQPAPCKTSPCDPCCC & PICCDPCGLQQGCCK \\
\cline { 2 - 2 } & PISCCPSSCTAVVCR \\
Example of protein & PCCWTSTGCQLLSVQAPCCR \\
R: Arginine & PPCCQPAPCK \\
TSPCDPCCC
\end{tabular}

K: Lysine

List of peptides generated by trypsin digestion

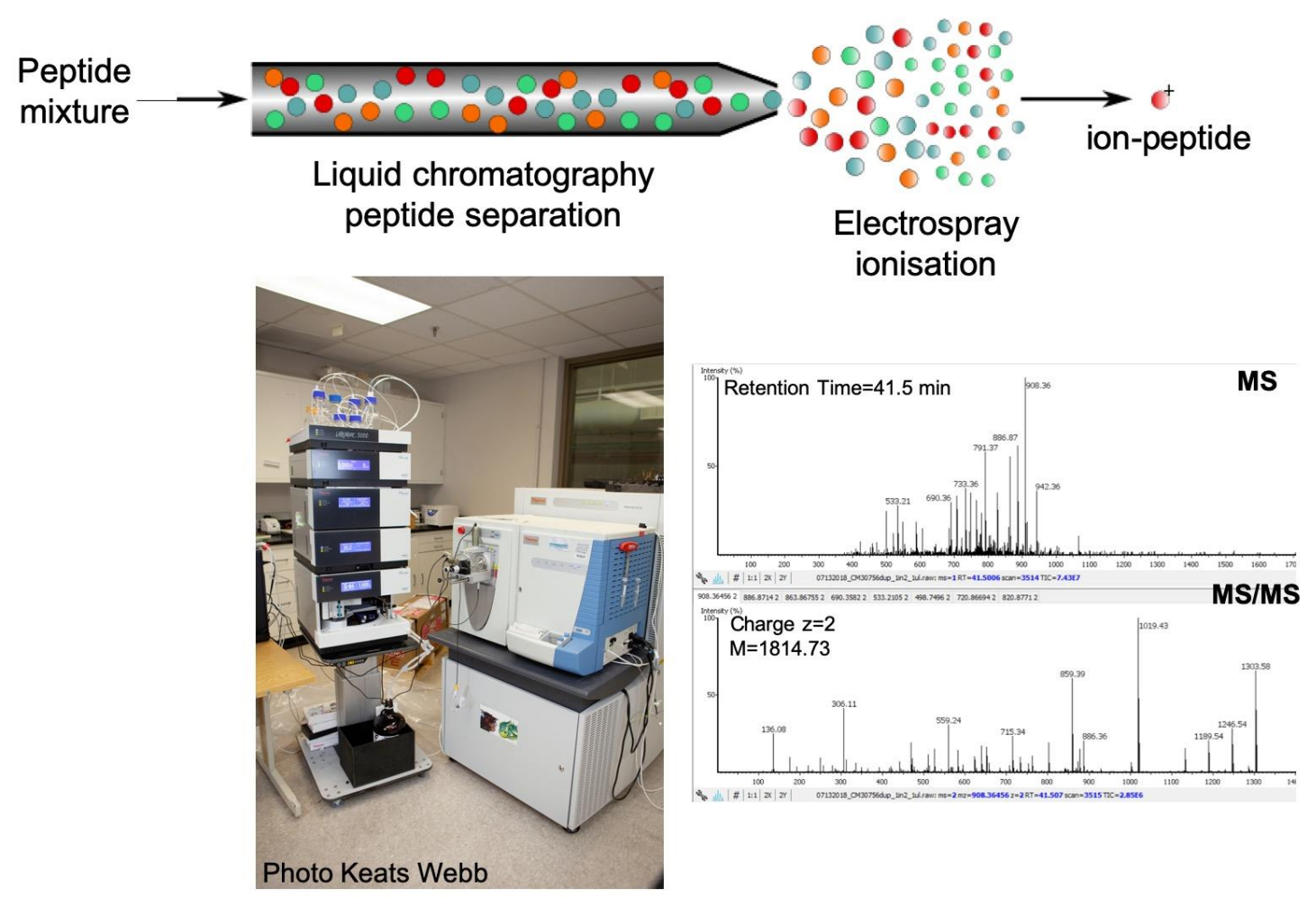

Fig. 7 Process of proteomics analysis from solubilization and digestion of proteins into peptides to peptide separation with Thermo 3000 nanoLC and mass spectrometry analysis with Thermo Elite Orbitrap mass spectrometer (photograph instruments by Keats Webb, Museum Conservation Institute, Smithsonian Institution), modified from "Philippe Hupé - Emmanuel Barillot, Laurence Calzone, Philippe Hupé, Jean-Philippe Vert, Andrei Zinovyev, Computational Systems Biology of Cancer Chapman \&amp; Hall/CRC Mathematical \&amp; Computational Biology, 2012”, CC BY-SA 3.0, https://commons.wikimedia.org/w/index.php?curid $=18770074$ 


\section{Samples tested for the project}

1. From the George Washington University (GWU) Textile Museum, Washington, D.C.:

The early Paracas knotted band had one atypical yarn that appeared to have certain qualities related to our study (Fig. 8 a and b). Turban band, alpaca hair, Peru, Ica Valley, Ocucaje, Grave lot 66 Cerro Max Uhle. Knotting, overhand knot, oblique twining. ${ }^{28}$ The sample failed to provide protein matches to chinchilla but instead came back with a mix of camel and alpaca matches. While the South-American camelids are close relatives to the Old-World camelids, some markers confirmed the identification to a South-American camelids such as Vicugna pacos (alpaca).
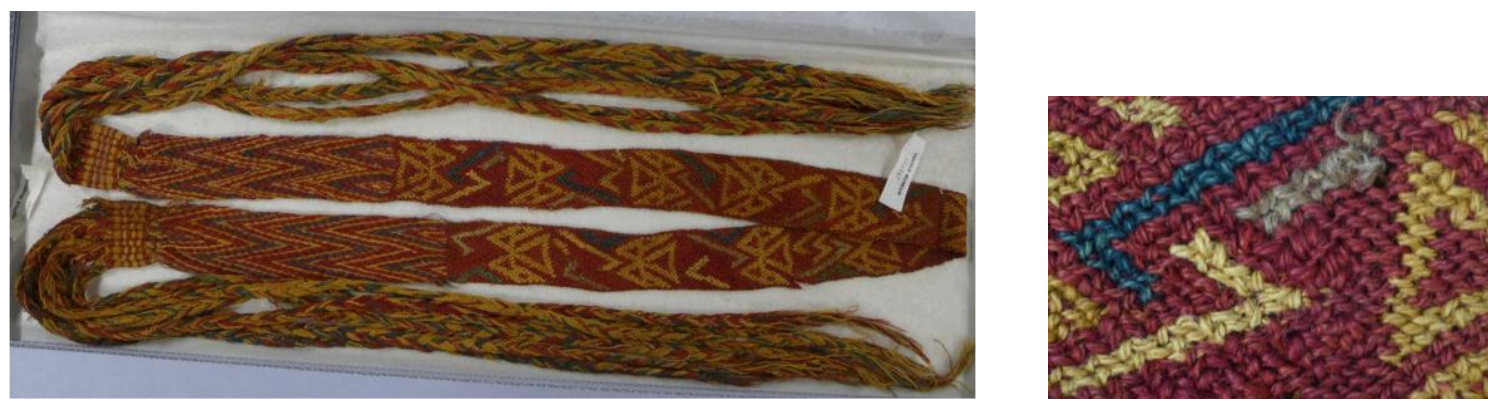

Fig. 8 a and b Paracas knotted band, The Textile Museum, Washington, D.C., 91.947, Acquired by George Hewitt Myers in 1957 and Detail

\section{2 and 3. From Rautenstrauch-Joest-Museum, Cologne (Germany)}

Two samples came from our colleague Petra Czerwinske-Eger in Cologne, from two textile fragments in her museum (Fig. 9) as she had noted an unusual physical aspect of the fiber used in one part of each of the textiles. ${ }^{29}$ The textiles, collected in Pachacamac in 1914, are likely from the Ychsma culture approx. 1000-1550 A.D. ${ }^{30}$ Scanning Electron Microscopy revealed interesting scale features including their long, fine overlap. Chinchillidae identification was indeed successful in the two textiles (Fig. 10). The percentage coverage obtained for the top protein matches were close to 70 percent, indicating high confidence in the identification as well as a reflection of the good preservation of the fibers. Some matches to cavia porcellus, the domestic guinea pig, indicated that while chinchilla was the best match, some peptides that do not belong to chinchilla were also identified.

\footnotetext{
${ }^{28}$ Thanks to Maria Fusco, Conservator and The Textile Museum/George Washington University for facilitating sample taking.

${ }^{29}$ Petra Czerwinske-Eger, Conservator Rautenstrauch-Joest-Museum, Cologne (Germany) "The object 32172 which was part of the Gretzer Collection and belongs to our collection since 1914 and the object 47199, which was taken in our collection in 1958. Both fragments are assigned to Pachacamac (Central coast)." Email to Elena Phipps Nov 12, 2018. Petra additionally supplied a scanning electron microscope image of object no. 47199, thanks to Dr. Anne Sicken Cologne Institute of Conservation Sciences (CICS) University of Applied Sciences Cologne (TH Köln) Rautenstrauch-Joest-Museum, Cologne (Germany).

${ }^{30}$ See Frame, Mary, Francisco Vallejo, Mario Ruales and Walter Tosso. 2012 Ychsma Textiles from a Late Horizon Burial at Armatambo. Nawpa Pacha. 32 (1): 43-94. Institute of Andean Studies, Berkeley. Also related examples in Bjerregaard, Lena and Huss, Torben, "PreColumbian Textiles in the Ethnological Museum in Berlin" (2017). Zea EBooks. 52.; https://digitalcommons.unl.edu/zeabook/52.
} 

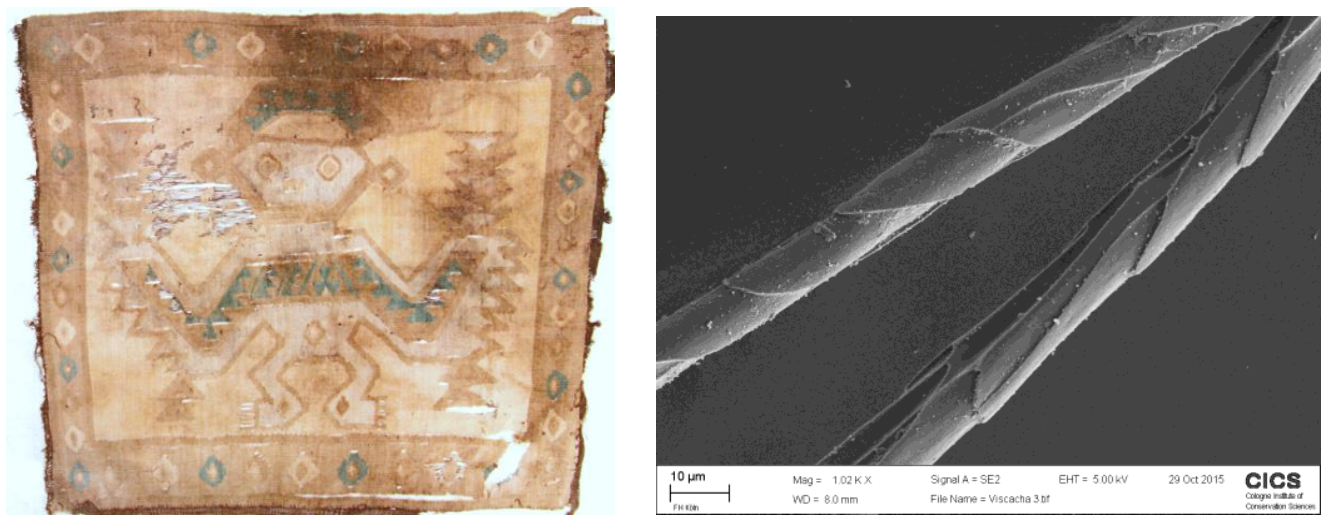

Fig. 9 Tapestry panel 32172, the Gretzer Collection, Rautenstrauch-Joest-Museum, Cologne.

Fig. 10 SEM photograph of fiber from object no. 47199, Rautenstrauch-Joest-Museum, Cologne (Germany) Photo by Dr. Anne Sicken Cologne Institute of Conservation Sciences (CICS) University of Applied Sciences Cologne (TH Köln).

\section{From the Cooper Hewitt Smithsonian Design Museum:}

A long, narrow tapestry band, late Nasca (?) had a yarn that was evidently of a special character (Fig. $11 \mathrm{a}$ and $\mathrm{b}$ ). We took a sample from the middle yarn composed of especially long and very soft fibers and strongly suspected it could be viscacha. ${ }^{31}$ Proteomics confirmed chinchillidae identification with matches similar to the ones obtained from the Cologne pieces.
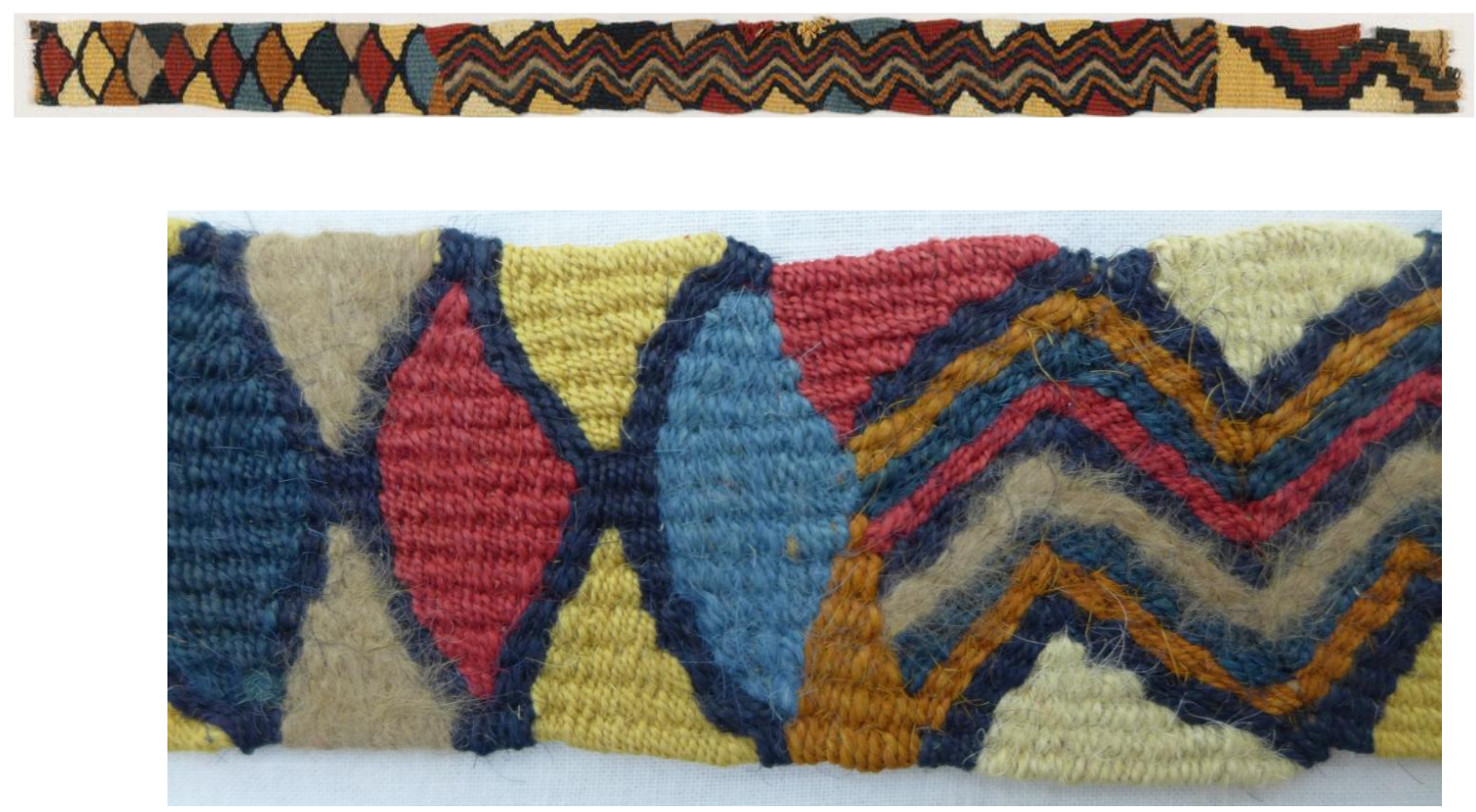

Fig. 11a and b Cooper Hewitt band, acc no. 1949-118-1-a, Nasca, Peru, 100 BC-800 AD. Tapestry weave with eccentric with some weft wrapping and use of non-horizontal wefts

\footnotetext{
${ }^{31}$ Cooper Hewitt acc no. 1949-118-1-a, Nasca, Peru, 100 BC-800 AD: Fragment of a tapestry-woven band with varied zigzag stripe and diamond patterns, in red, yellow, green, black and tan. Medium: cotton and wool (likely camelid hair). Technique: tapestry weave; with some weft wrapping and use of non-horizontal wefts. Additionally, from the Cooper Hewitt, we re-tested samples from the previous study, Cooper Hewitt acc no. 1902-1-374 tapestry band with feathers and rabbit hair, with new method of Protein analysis.
} 


\section{From the American Museum of Natural History:}

A number of yarns were sampled from this interesting Inca period coca bag from the American Museum of Natural History, B/3810 (Fig. 12). The bag had previously been suspected of being composed with viscacha, by Junius Bird. ${ }^{32}$ The lighter brown stripes in the bag are the so-called special left-spun yarns called 'lloq'e' mentioned earlier in the discussion above. Of the eight samples tested from this bag, one sample was identified as a camelid, six were matched to chinchilla, and the last one did not yield proteins but was rather identified as an unmixed plant fiber used at the top opening of the bag. Microscopic examination (SEM) confirmed the plant nature of the fiber and identification as cotton.

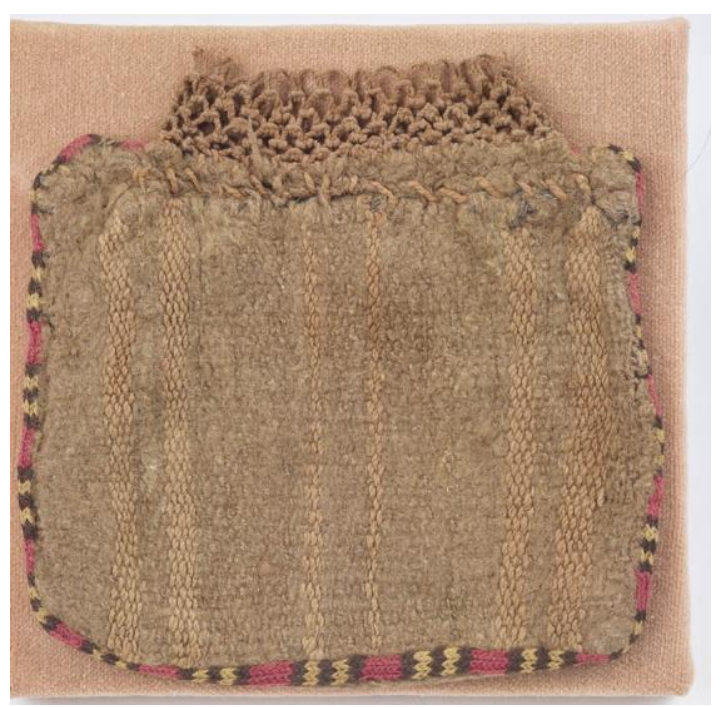

Fig. 12 Inca period coca bag with embroidered edging and looped portion at opening. American Museum of Natural History, New York. B/3810. (Photo courtesy The Division of Anthropology, AMNH.)

\begin{tabular}{|c|c|c|c|c|}
\hline & \multicolumn{2}{|c|}{ Chinchillidae } & Camelidae & Cotton \\
\hline $\begin{array}{l}\text { 1. George Washington University (GWU) Textile } \\
\text { Museum, Washington, D.C. }\end{array}$ & & & 91.947 & \\
\hline $\begin{array}{l}2 \text { and 3. Rautenstrauch-Joest-Museum (RJM), } \\
\text { Cologne, Germany }\end{array}$ & $\begin{array}{l}\text { RJM } \\
32172\end{array}$ & $\begin{array}{c}\text { RJM } \\
47199\end{array}$ & & \\
\hline 4. Cooper Hewitt, Smithsonian Design Museum, NY & \multicolumn{2}{|c|}{ 1949-118-1-a } & & \\
\hline \multirow[b]{2}{*}{ 5. American Museum of Natural History (AMNH) } & \multicolumn{4}{|c|}{$\mathbf{B} / \mathbf{3 8 1 0}$} \\
\hline & \multicolumn{2}{|c|}{$\begin{array}{c}\mathbf{A}_{1}: \text { warp } \\
\mathbf{A}_{2}: \text { sewing thread } \\
\mathbf{A}_{3} \text { : warp } \\
\mathbf{B}_{2} \text { (back): weft } \\
\mathbf{B}_{3} \text { (back): warp } \\
\mathbf{B}_{4} \text { (back): weft }\end{array}$} & $\begin{array}{c}\text { B1 (back): } \\
\text { sewing } \\
\text { thread }\end{array}$ & $\begin{array}{l}\text { B5 (back): } \\
\text { fiber from } \\
\text { knotted netting } \\
\text { portion }\end{array}$ \\
\hline
\end{tabular}

Table 1 Summary of samples and their results.

\footnotetext{
${ }^{32}$ Thanks to Vuka Roussakis who identified the fiber, and brought the bag to my attention.
} 


\section{Identification of viscacha markers}

In order to accurately determine whether the samples were viscacha and not chinchilla and to possibly tell the different species apart, reference samples of the three viscacha species were tested by proteomics to create an in-house database of markers. Specimens of northern, southern and plains viscacha were obtained from natural history collections at the American and National Museums of Natural History, and the corpus of MS/MS spectra generated analyzed to look for novel markers.

New peptides were identified by looking for amino acid substitutions in the known sequences of chinchilla. By using a technique called de novo sequencing we can assemble the sequence by adding the amino acids corresponding to the mass differences between peaks (Fig. 13). For example, the sequence EVEEWYTK (in green, figure Y) is a newly sequenced peptide specific to the Lagidium genus where the threonine in position 8 in the chinchilla sequence is substituted by a lysine $T_{8} \rightarrow K$. Since trypsin cuts after arginine and lysine, the peptide is also shorter in the viscacha with a mass $\mathrm{Mr}=1082.4920 \mathrm{Da}$, instead of $\mathrm{Mr}=1897.8581$ for EVEEWYTTQTEELNK in chinchilla. In blue is a sequence specific to the Lagostomus genus; up to three substitutions were detected $\mathrm{G}_{2} \rightarrow \mathrm{S}, \mathrm{R}_{10} \rightarrow \mathrm{G}$ and $\mathrm{I}_{12} \rightarrow \mathrm{V}$.

(a)

>XP_005394457.1 PREDICTED: keratin, type I cuticular Ha1 [Chinchilla lanigera]

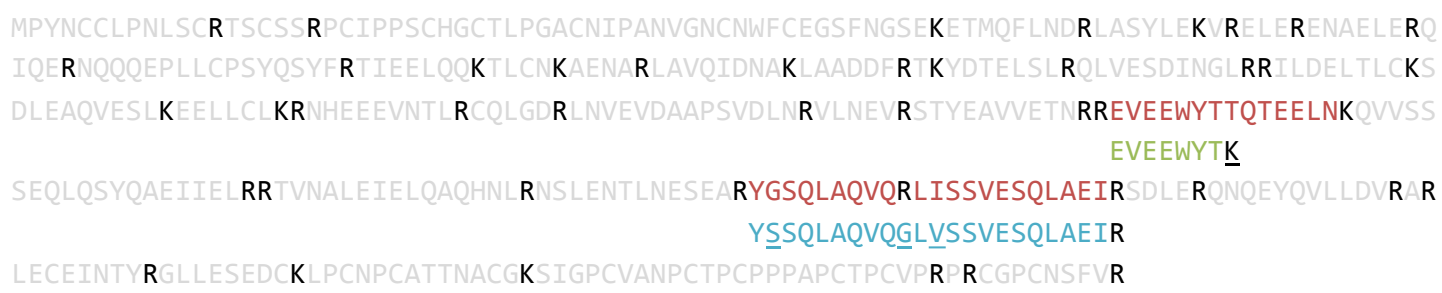

(b)

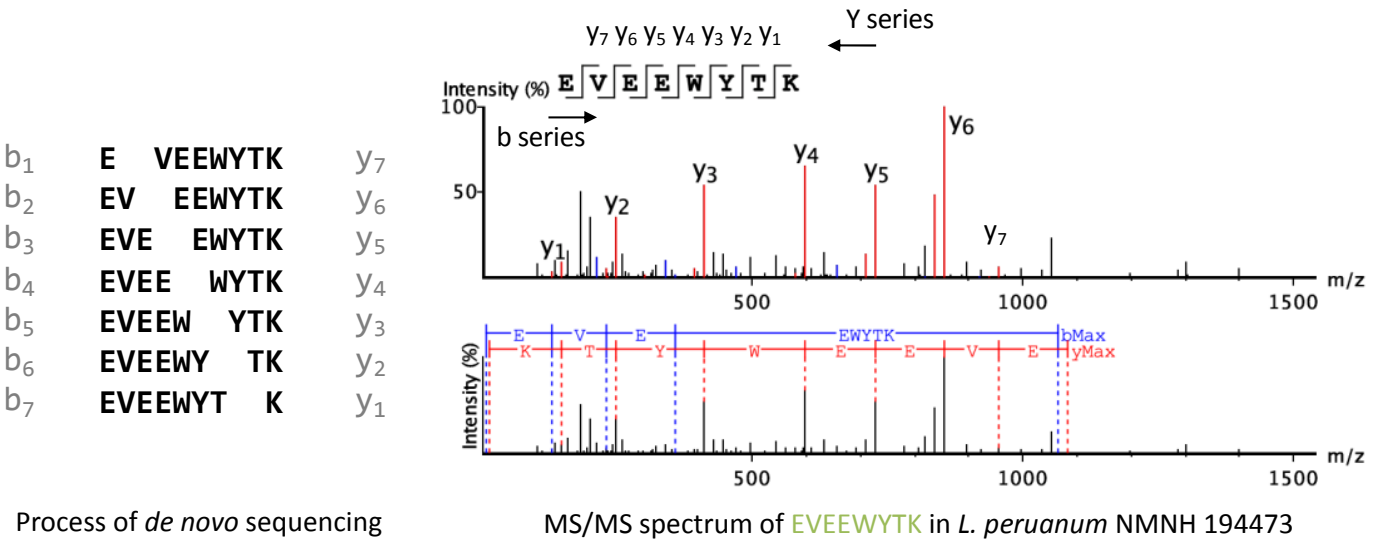

Fig. 13 de novo process to identify new peptide markers in viscacha. On top (a) is one of the main keratin protein from Chinchilla (in black are the lysine and arginine residues). In green is a new Lagidium peptide and in blue a new Lagostomus peptide, identified through automated de novo sequencing using Peaks 8.5 DENOVO @ 2020| Bioinformatics Solutions Inc. Underlined are the amino acids that are substituted in the viscacha, compared to chinchilla in red. (b) de novo sequencing of the Lagidium peptide, showing the peaks (y series in red, b series in blue) corresponding to the different segments of the sequence 
The process was repeated many times, and resulted in a solid list of markers, some shared by multiple species, some specific to Chinchilla, Lagidium, or Lagostomus only. The summary Table 2 indicates the number of peptides identified for the different genera. None of the Chinchilla or Lagostomus-specific peptides were found in any of the samples, while all markers detected were present in the Lagidium sp. with all but one sample (A3) having at least one unique marker to Lagidium. For instance, peptide EVVWYTK, a robust marker for Lagidium, was found in all samples but A3.

\begin{tabular}{|l|c|c|c|c|c|c|c|c|c|}
\hline \multirow{2}{*}{ Genus (total number of markers) } & \multicolumn{2}{|c|}{ RJM } & \multicolumn{5}{c|}{ CH } & \multicolumn{4}{|c|}{ AMNH B/3810 } \\
\cline { 2 - 9 } & $\mathbf{3 2 1 7 2}$ & $\mathbf{4 7 1 9 9}$ & $\mathbf{1 9 4 9 - 1 1 8 - 1 - a}$ & A1 & A2 & A3 & B2 & B3 & B4 \\
\hline Chinchilla (2) & 0 & 0 & 0 & 0 & 0 & 0 & 0 & 0 & 0 \\
\hline Lagidium (4) & 1 & 2 & 2 & 1 & 1 & 0 & 2 & 3 & 2 \\
\hline Lagostomus (8) & 0 & 0 & 0 & 0 & 0 & 0 & 0 & 0 & 0 \\
\hline Chinchilla/Lagidium (6) & 2 & 4 & 6 & 4 & 4 & 1 & 5 & 6 & 5 \\
\hline Lagidium/Lagostomus (1) & 0 & 1 & 1 & 0 & 1 & 0 & 0 & 1 & 1 \\
\hline
\end{tabular}

Table 2 Number of peptides identified in the textile samples for each genus. In green are the markers present in Lagidium.

\section{Conclusions}

Our study has helped to highlight the importance of identification of the fibers used in ancient textiles that helps to link cultural traditions to the archaeological record. Through cultural and scientific analysis, we found significance in the fact that the special fibers of viscacha were used in the Andes within ritual and ceremonial context, from the past and up until today, and their presence in textiles from various regions is notable. Utilizing reference samples available in museum specimen collections of the various animals within the family, the identification of protein markers, previously unstudied, were able to be documented to enable proceeding with the identification process from unknown samples. We will eagerly seek other potential textile examples that could begin to fill out our understanding of the span of time when spinning viscacha hair was incorporated into Andean textile traditions. ${ }^{33}$

\footnotetext{
${ }^{33}$ Since this paper was presented at the TSA conference in Oct 2020, Meredith Montague, Textile Conservator at the MFA Boston - after hearing our presentation -- was preparing a Paracas embroidered turban for installation and thought the ground cloth had special properties, and so she contacted us. We are currently processing a sample from this textile to include in our study. Even before we are able to do the analysis, we can see, however, from Meredith's microscopic photograph that the fibers appear to be potentially viscacha, and not camelid - so we are relatively confident that they will be a positive. If so, this would be the earliest woven textile with viscacha, and a rather extraordinary find in a Paracas period example.
} 